\section{First report of Gongylonema sp. in a free ranging callitrichid from the Brazilian Atlantic Forest: case report}

[Primeiro relato de Gongylonema sp. em um calitriquídeo de vida livre proveniente da Mata Atlântica brasileira: relato de caso]

\author{
A.R. Oliveira ${ }^{1}$, T.D. Souza ${ }^{2}$, M.C. Flecher ${ }^{2}$, C.H. Gardiner ${ }^{3}$, R.L. Santos ${ }^{1 *}$ \\ ${ }^{1}$ Universidade Federal de Minas Gerais - Belo Horizonte, MG \\ ${ }^{2}$ Universidade Vila Velha - Vila Velha, ES \\ ${ }^{3}$ Joint Pathology Center - Silver Spring - MD, USA
}

A.R. Oliveira

https://orcid.org/0000-0002-9031-792X T.D. Souza

https://orcid.org/0000-0003-0666-8207 M.C. Flecher
https://orcid.org/0000-0001-8403-538X
C.H. Gardiner https://orcid.org/0000-0002-4373-5395 R.L. Santos

https://orcid.org/0000-0002-4830-0470

\begin{abstract}
This is the first report of parasitism by Gongylonema sp. in a free-ranging callitrichid from the Atlantic forest of Espírito Santo, Brazil. A juvenile male of Geoffroy's marmoset (Callithrix geoffroyi) was euthanized due to poor prognosis, then necropsied. Samples of the tongue were collected for routine histological processing. Microscopically, there were transversal sections of adult nematodes within the epithelial layer of the mucosa of the tongue. Lingual scraping demonstrated a small number of oval embryonated eggs with a thick capsule. The morphology of the adult parasites and the eggs, associated with its location, were compatible with the Spirurida nematode of the genus Gongylonema. Further studies are needed to evaluate the impact of this parasite on free-ranging callitrichid populations.
\end{abstract}

Keywords: marmoset, gullet worm, primate, spirurida, tongue

\title{
RESUMO
}

Este é o primeiro relato de parasitismo por Gongylonema sp. em um calitriquídeo de vida livre proveniente da Mata Atlântica do Espírito Santo, Brasil. Um sagui-da-cara-branca (Callithrix geoffroyi), macho, jovem, foi eutanasiado, devido a prognóstico desfavorável, e necropsiado. Fragmentos de língua foram coletados para processamento histológico de rotina. Microscopicamente, havia cortes transversais de nematoides adultos na mucosa da língua. Na raspagem da mucosa da língua, foi observada pequena quantidade de ovos larvados ovais com cápsula espessa. A morfologia do parasita adulto e dos ovos, associada à localização do agente, é compatível com nematoide Spirurida do gênero Gongylonema. São necessários estudos adicionais para avaliar o impacto desse parasito nas populações de calitriquídeos de vida livre.

Palavras-chave: sagui, parasita do esôfago, primata, Spirurida, língua

\section{INTRODUCTION}

Gongylonema sp., also called gullet worm, is a mildly pathogenic nematode parasite of the upper digestive tract of several species of mammals and birds (Cappucci et al., 1982). In primates, including humans, the parasite has a preference for the oral cavity, particularly the palate, lips, and tongue (Sato et al., 2005). Transmission occurs by ingestion of intermediate hosts, which includes beetles and cockroaches (Cappucci et al., 1982).

Recebido em 20 de abril de 2018

Aceito em 9 de novembro de 2018

*Autor para correspondência (corresponding author)

E-mail: rsantos@vet.ufmg.br
Gongylonematiasis has been described in neotropical primates, i.e., Goeldi's monkey (Callimico goeldii), golden lion tamarins (Leontopithecus rosalia) cotton-top tamarins (Saguinus oedipus) and golden-headed lion tamarins (Leontopithecus chrysomelas) from North American zoos (Duncan et al., 1995; Adkesson et al., 2007), common marmosets (Callithrix jacchus) from a Germany research facility (Brack, 1996), and squirrel monkeys (Saimiri boliviensis) from a Japanese zoo (Sato et al., 2005). However, all previous reported cases affected animals in captivity. 
Callithrix geoffroyi, popularly known as Geoffroy's marmoset, is found in the Atlantic Forest of Espírito Santo, extending to the southeastern Bahia and eastern Minas Gerais. As in other callitrichids, its diet is composed predominantly of gum, fruits, insects, and small vertebrates (Passamani, 1998; Passamani and Rylands, 2000). Although it has previously been described in captive calitriquids in other countries (Brack, 1996; Adkesson et al., 2007), to the best of our knowledge there is no previous report of this parasite in non-human primates in Brazil.

\section{CASE REPORT}

A free-ranging juvenile male Geoffroy's marmoset (Callithrix geoffroyi) was found apathic in the district of Maruípe, Vitória (State of Espírito Santo, Brazil). The animal was sent for treatment at a wildlife screening center of the Instituto Brasileiro do Meio Ambiente e dos Recursos Naturais Renováveis (IBAMA). Physical examination showed marked cachexia, severe purulent and ulcerative bilateral keratoconjunctivitis, and complete fracture of right tibia and fibula.

Due to poor prognosis the animal was euthanized, and immediately sent to necropsy at the Animal Pathology Laboratory of Universidade Vila Velha. In addition to these clinical findings, necropsy and histopathology also showed mild jaundice and a proliferative and sclerosing cholangiohepatitis associated with numerous trematode parasites compatible with Platynosomum sp., which was histologically characterized by a digestive tract, absence of coelom or pseudocoelom, and presence of both male and female reproductive organs (ovary, uterus, and testis). During necropsy, in spite of absence of gross lesions, samples of the tongue were collected, fixed in a $10 \%$ formalin buffered solution, sent to routine histological processing, and stained with hematoxylin and eosin (HE). Microscopically, there were cross sections of adult nematodes within the epithelial layer of the mucosa of the tongue. Parasites were slightly compressing the adjacent epithelial tissue associated with a mild neutrophilic inflammatory reaction (Figure 1). Parasites were also observed in the epithelial layer of the soft palate mucosa.

Morphologically, the nematode had a thick cuticle with winged lateral alae, coelomyarian musculature, a small intestine composed of columnar cells, prominent lateral cords, free eosinophilic fluid in the pseudocoelom, and one large testis (Figure 2).

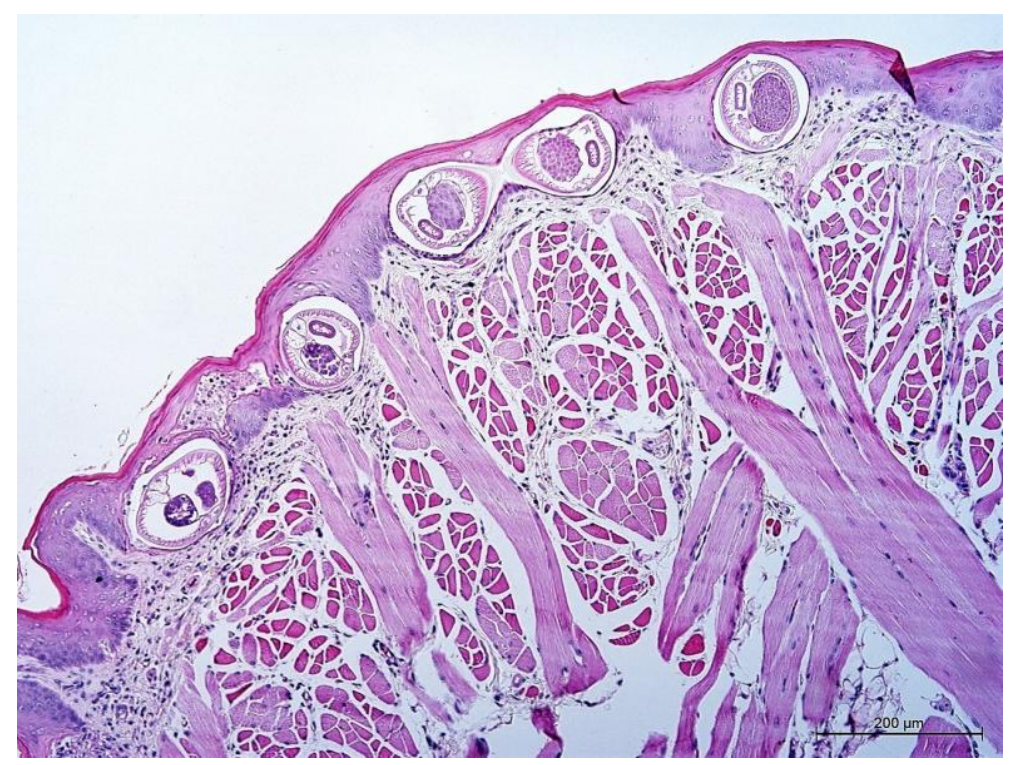

Figure 1. Gongylonema sp. in the tongue of a free-ranging Geoffroy's marmoset (Callithrix geoffroyi) from Espírito Santo, Brazil. Tongue with five cross sections of spirurid parasite within the epithelial layer of the mucosa, compatible with a serpentine path, HE, 100x, scale bar $=200 \mu \mathrm{m}$. 

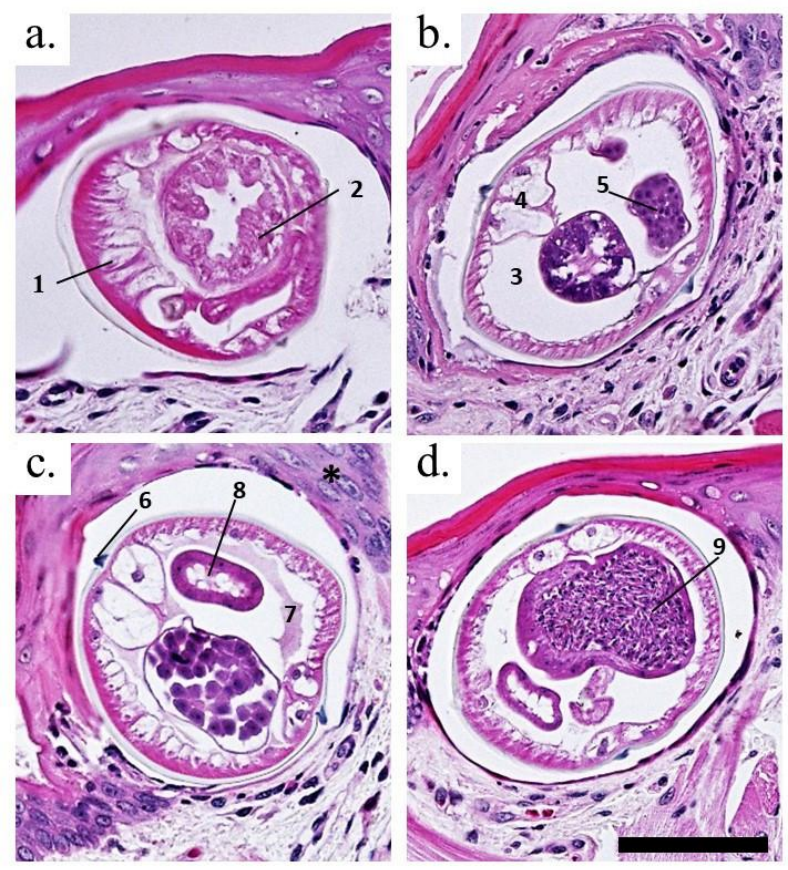

Figure 2. Gongylonema sp. in the tongue of a free-ranging Geoffroy's marmoset (Callithrix geoffroyi) from Espírito Santo, Brazil. Morphological features of the parasite: transversal sections (a, b, c, d). 1 coelomyarian musculature; 2 - testis; 3 - pseudocoelom; 4 - prominent lateral cords; 5 - testis; 6 - winged cuticular lateral alae; 7 - free eosinophilic fluid in the pseudocoelom; 8 - small intestine composed of columnar cells; 9 - testis with developing spermatozoa. Observe a slightly compression of the adjacent epithelial tissue $(*)$, HE, 200x, scale bar $=50 \mu \mathrm{m}$.

After histopathological findings, lingual scrapping was performed of the remaining formalized tongue, with a scalpel blade and the scraped material was deposited on a glass slide and mixed with $0.1 \mathrm{~mL}$ of saline. This material was evaluated by light microscopy for the presence of adult parasites and eggs. There were no adult parasites in this preparation, but a small number of small, thick-shelled, oval, embryonated eggs were observed (Figure 3 ).

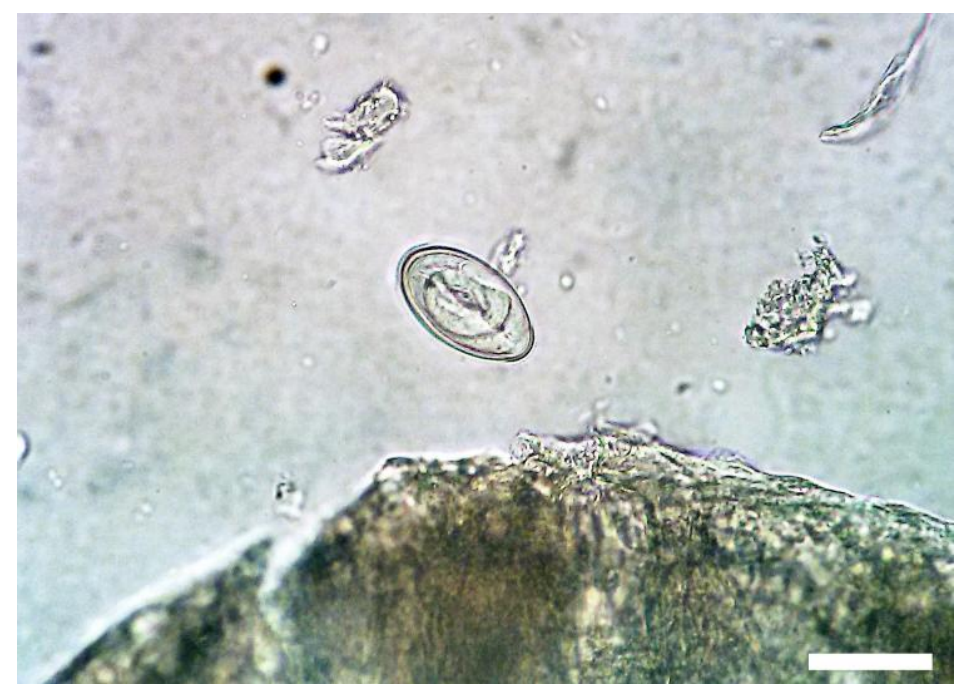

Figure 3. Gongylonema sp. in a Geoffroy's marmoset (Callithrix geoffroyi) from Espirito Santo, Brazil. Embryonated egg observed at lingual scrapping. Scale bar $=50 \mu \mathrm{m}$. 


\section{DISCUSSION}

To the best of our knowledge, this is the first report of parasitism by Gongylonema sp. in a free-ranging non-human primate from Brazil. Histopathology was instrumental for identifying the parasite in this case. Presence of digestive tract and pseudocoelom are features of a nematode (Gardiner and Poynton, 1999). All Spirurids have coelomyarian musculature and, some species, such as Gongylonema sp., will also have thick cuticle with alar ornamentation, eosinophilic fluid in the pseudocoelom, prominent lateral cords, and a small intestine compose of cuboidal to columnar epithelial cells (Gardiner and Poynton, 1999). Although we did not observe any female parasite with eggs in the histologic sections available, lingual scraping demonstrated eggs with morphology compatible with that of the Spirurid order, since the eggs were oval, thick-shelled, and embryonated. These morphological features associated with oral mucosae distribution in the primate host (Duncan et al., 1995; Bleier et al., 2005; Sato et al., 2005; Adkesson et al., 2007) supported a conclusive classification of the parasite as Gongylonema sp. Previous reports describe a case affecting a human patient from Belo Horizonte (Waisberg et al., 2018), and other report affecting a white bellied opossum from same area (Quintão e Silva and Costa, 1999), which indicates the presence of this parasite at the Atlantic forest and peri-urban areas in Brazil.

Sato et al. (2005) described a high incidence of $25.5 \%$ of gongylonematiasis in a captive squirrel monkey colony at a Japanese zoo. However, prior to that study, the parasitism was considered an incidental finding. Gongylonematiasis is difficult to diagnose and may have transient symptoms or clinical signs varying from months to years (Xiaodan et al., 2018). In humans, sometimes it may be misdiagnosed as oral candidiasis or psychotic symptoms (Molavi et al., 2006; Ayala and Yencha, 2012). Lingual scraping is an efficient technique to detect Gongylonema sp. in non-human primate colonies (Sato et al., 2005), but still underestimates the infection since it has a low sensitivity (Adkesson et al., 2007). In our case, only few eggs of Gongylonema sp. were observed using that technique, although lingual scraping in this case was performed on fixed tissues, whereas all previously reported cases were done on nonformalized tissues.

Although Gongylonema sp. has been considered nonpathogenic in most previously reported cases, in non-human primates there are reports of gongylonematiasis leading to intense itching and ptyalism (Brack, 1996; Adkesson et al., 2007), that could result in some degree of psychological stress (Brack, 1996; Sato et al., 2005). It has been also associated with septicemia (Duncan $e t$ al., 1995), and with development of an esophageal squamous cell carcinoma (Bleier et al., 2005). In this case, there was no clinical history available, and considering the absence of gross findings and only mild histopathological changes, it was considered an incidental finding, with no relevance to the death of the animal.

In conclusion, this report clearly demonstrated that Gongylonema sp. circulates among wild callitrichids populations from the Brazilian Atlantic forest. Further studies are needed to evaluate the impact of this parasite on wild callitrichid populations as well as its relevance for public health.

\section{ACKNOWLEDGEMENTS}

Research at R. L. Santos' laboratory is funded by $\mathrm{CNPq}$ (Conselho Nacional de Desenvolvimento Científico e Tecnológico, Brasilia, DF, Brazil), FAPEMIG (Fundação de Amparo a Pesquisa do Estado de Minas Gerais, Belo Horizonte, MG, Brazil), and CAPES (Coordenação de Aperfeiçoamento de Pessoal de Nível Superior, Brasilia, DF, Brazil). R. L. Santos was awarded a CNPq research fellowship.

\section{REFERENCES}

ADKESSON, M.J.; LANGAN, J.N.; PAUL A. Evaluation of control and treatment of Gongylonema spp. infections in callitrichids. $J$. Zoo. Wildl. Med., v.38, p.27-31, 2007.

AYALA, M.A.; YENCHA, M.W. Gongylonema: a parasitic nematode of the oral cavity. Arch. Otolaryngol. Head Neck Surg., v.138, p.10821084, 2012. 
BLEIER, T.; HETZEL, U.; BAUER, C. et al. Gongylonema pulchrum infection and esophageal squamous cell carcinoma in a vari (Lemur macaco variegate; Kehr 1792). J. Zoo. Wildl. Med., v.36, p.342-345, 2005.

BRACK, M. Gongylonematiasis in the common marmoset (Callithrix jacchus). Lab. Anim. Sci., v.46, p.266-270, 1996.

CAPPUCCI, D.T.; AUGSBURG, J.K.; KLINCK, P.C. Gongylonemiasis. In: STEELE, J.H. (Ed.). CRC Handbook series in zoonoses section c: parasitic zoonoses. Boca Raton: CRC Press, 1982. v.2, p.181-192.

DUNCAN, M.; TELL, L.; GARDINER, C.H.; MONTALI, R.J. Lingual gongylonemiasis and pasteurellosis in Goeldi's monkeys (Callimico goeldii). J. Zoo. Wildl. Med., v.26, p.102-108, 1995.

GARDINER, C.H.; POYTON S.L. Morphological characteristics of nematodes. In: . (Eds.). An atlas of metazoan parasites in animal tissue. Washington DC: Armed Forces Institute of Pathology, 1999. p.3-41.

MOLAVI, G.H.; MASSOUD, J.; GUTIERREZ, Y. Human Gongylonema infection in Iran. $J$. Helminthol., v.80, p.425-428, 2006.
PASSAMANI, M. Activity budget of geoffroy's marmoset (Callithrix geoffroyi) in an Atlantic Forest in Southeastern Brazil. Am. J. Primatol., v.46, p.333-340, 1998.

PASSAMANI, M.; RYLANDS, A.B. Feeding behavior of geoffroy's marmoset (Callithrix geoffroyi) in an Atlantic Forest Fragment of South-eastern Brazil. Primates, v.41, p.27-38, 2000.

QUINTÃO E SILVA, M.G.; COSTA, H.M. Helminths of white bellied opossum from Brazil. J. Wildl. Dis., v.35, p.371-374, 1999.

SATO, H.; UNE, Y., TAKADA, M. High incidence of gullet worm, Gongylonema pulchrum in a squirrel monkey colony in a zoological garden in Japan. Vet. Parasitol., v.127, p.131-137, 2005.

WAISBERG, V.; LIMA, W.S.; VASCONCELOS-SANTOS, D.V. Intraocular Gongylonema infection: first case in humans. Ocul. Immunol. Inflamm., v.26, p.595-597, 2018.

XIAODAN, L.; ZHENSHENG, W.; YING, H. et al. Gongylonema pulchrum infection in the human oral cavity: a case report and literature review. Oral. Surg. Oral. Med. Oral. Pathol. Oral. Radiol., v.125, p.49-53, 2018. 